\title{
Human pluripotent stem cell differentiation into authentic striatal projection neurons
}

Alessia Delli Carri ${ }^{1,3}$, Marco Onorati ${ }^{1,3}$, Valentina Castiglioni ${ }^{1}$, Andrea Faedo ${ }^{1}$,

Stefano Camnasio ${ }^{1}$, Mauro Toselli ${ }^{2}$, Gerardo Biella ${ }^{2}$ and Elena Cattaneo ${ }^{1,4}$

${ }^{1}$ Department of Biosciences and Center for Stem Cell Research, Università degli Studi di Milano 20133

Milan, Italy

${ }^{2}$ Department of Biology and Biotechnology, University of Pavia, 27100 Pavia, Italy

${ }^{4}$ Corresponding author, e-mail: elena.cattaneo@unimi.it

${ }^{3}$ These authors contributed equally to this work.

\section{Keywords}

Striatal neuronal differentiation; Medium spiny neurons; DARPP-32; Huntington's disease; Directed differentiation; Human embryonic stem cells; Human pluripotent stem cells

\section{Disclosures}

The authors indicate no potential conflicts of interest.

\section{Running head}

Striatal neurons from pluripotent stem cells

\begin{abstract}
Here we present the principles and steps of a protocol that we have recently developed for the differentiation of hES/iPS cells into the authentic human striatal projection medium spiny neurons (MSNs) that die in Huntington's Disease (HD). Authenticity is judged by the convergence of multiple features within individual cells. Our procedure lasts 80 days and couples neural induction via BMP/TGF- $\beta$ inhibition with exposure to the developmental factors sonic hedgehog (SHH) and dickkopf1 (DKK-1) to drive ventral telencephalic
\end{abstract}


specification, followed by terminal differentiation [1]. Authenticity of the resulting neuronal population is monitored by the appearance of $\mathrm{FOXG1} 1^{+} / \mathrm{GSX} 2^{+}$progenitor cells of the lateral ganglionic eminence (LGE) at day 15-25 of differentiation, followed by appearance of CTIP2-, FOXP1- and FOXP2-positive cells at day 45. These precursor cells then mature into $\mathrm{MAP}^{+} / \mathrm{GABA}^{+}$neurons with $20 \%$ of them ultimately coexpressing the DARPP-32 and CTIP2 diagnostic markers and carrying electrophysiological properties expected for fully functional MSNs.

The protocol is characterized by its replicability in at least three human pluripotent cell lines. Altogether this protocol defines a useful platform for in vitro developmental neurobiology studies, drug screening, and regenerative medicine approaches.

\section{Introduction}

Human pluripotent stem (hPS) cells (both embryonic and induced) have emerged as a powerful tool for developmental biology studies, genetic and chemical screens, and regenerative medicine for neurological diseases, as they can generate different neuronal subtypes [2]. In particular, in the last two years, a number of important protocols have been developed largely based on the knowledge that, in vivo, specific neural progenitors are induced along the rostro-caudal and dorsal-ventral axes by secreted morphogens. The combined and specific application of a few of these morphogens, such as SHH, FGF8, retinoic acid, wingless-type MMTV integration site (WNT) families and its inhibitors, has made it possible to produce spinal motor neurons, neocortical progenitors and neurons [3], forebrain glutamatergic and cholinergic neurons from human pluripotent stem cells $[3,4]$. Authentic dopaminergic mesencephalic neurons have also been obtained through induction of floor plate fate and application of ventralizing signals [5] [6].

Earlier attempts at obtaining differentiation into striatal neurons have made use of an undefined stromal coculture method to which hES cells were exposed [7]. Subsequently, a culture system involving embryoid bodies formation and exposure to $200 \mathrm{ng} / \mathrm{ml} \mathrm{SHH}$ was used to obtain transplantable LGE-like progenitors [8]. However, both methods failed to reveal a ventral telencephalic character in the emerging progenitors nor they demonstrated the acquisition of a distinctive MSN character in the generated neurons, that were not deeply characterized from a neurochemical and/or electrophysiological point of view. In contrast, we have 
recently validated and published a procedure for the generation of authentic human MSNs from both hES and hiPS cells, based on an ontogeny-recapitulating three-step method that incorporates neural induction, patterning, and terminal differentiation [9]. Here we provide a detailed account of the procedure. The first step towards the development of the mature forebrain is neural induction, which generates the neural plate, begins during gastrulation, and at a general level is repressed by TGF- $\beta$ signaling. Accordingly, several authors have used the dual SMAD inhibition strategy [1] to efficiently drive the formation of anterior neuroepithelial stem cells from hES cells. In our protocol we have successfully adopted this strategy to obtain anterior neural progenitors.

In vivo, Shh is expressed in the ventral telencephalon and hypothalamus and is essential to the regionalization of the subpallium [10] [11] while along the dorsal midline, secreted molecules of the bone morphogenetic proteins (BMP) and WNT families control patterning of the medial and dorsal pallium. These telencephalic patterning centers initiate regionalization of the telencephalon by inducing graded expression of transcription factors (TFs) in neural progenitors across the rostro-caudal and dorso-ventral axes [12]. We found that addition to the neuroectodermal cultures of the secreted molecules SHH and DKK-1 (a WNT inhibitor) fully recapitulate their in vivo functions, as judged by the appearance of FOXG1 $1^{+} / \mathrm{GSX} 2^{+}$ventral telencephalic progenitors from the neuralizing hES cells. We also found that at subsequent days of in vitro differentiation cells mature into electrophysiological active DARPP- $32^{+} / \mathrm{CTIP} 2^{+}$striatal MSNs, as found in vivo in human [9]. Our protocol generates a large amount of GABAergic neurons (around 80\%) with a large portion of them being CTIP2 ${ }^{+} /$calbindin $^{+}$. Most importantly, at day $80,20 \%$ of the neurons are DARPP-32 $2^{+}$ MSNs co-expressing CTIP2 and carrying dopamine D2 and adenosine A2a receptors. Upon depolarization, these neurons elicit trains of action potentials, show consistent dopamine-dependent neuromodulation and synaptic activity.

Importantly, in the described protocol, the progressive maturation of the cells is accompanied by a timedependent modulation of the expression of specific progenitor and neuronal TFs and neurochemical markers and similar fluctuations were observed in vivo during human fetal brain development. For instance, our culture system generates an enriched population of GSX2 $2^{+}$LGE progenitors starting from 2 weeks of neural 
induction, whereas PAX6 is expressed before SOX1 and FOXG1, and DARPP-32 follows CTIP2 expression during differentiation.

We therefore propose the protocol described below as suitable for the derivation of authentic LGE progenitor cells and functional MSNs from hES and iPS cells.

\section{Materials, Reagents and Solutions}

Materials

Cell culture equipment

- $\quad$ T-75 Flasks: Iwaki, \#3123-075

- 35-mm polystirene Petri dishes: Iwaki, \#3000-035

- 60-mm polystirene Petri dishes: Iwaki, \#3010-060

- 6-well plates: Iwaki, \#3810-006

- 12-well plates: Iwaki, \#3815-012

- $50 \mathrm{ml}$ conical tubes: Iwaki, \#2345-050

- 15 ml conical tubes: Iwaki, \#2325-015

- 2, 5, 10, 25, $50 \mathrm{ml}$ sterological pipettes: Euroclone, \#CC4485, \#CC4487, \#CC4488, \#CC4489, \#CC4490

- $\quad$ 100-1000 $\mu 1$ tips: Euroclone, \#CC4846

- 20-200 $\mu 1$ tips: Euroclone, \#CC4845

- $\quad$ 10-10 $\mu$ l tips: Starlab, \#S1111-3000

- Stericup ${ }^{\circledR}$ Unit Filter: Millipore, \#SCGPU05RE

- Coverglasses 18 mm diameter: Deckglaser, \#DX-CR18

- Countess chamber slides: Invitrogen, \#C10228

- Countess ${ }^{\circledR}$ automated cell counter: Invitrogen, \#C10227

- Millex ${ }^{\circledR}$ Syringe-driven filter unit $0.22 \mu \mathrm{m}$ filter: Millipore, \#SLGV033RS

- Water bath, $37^{\circ} \mathrm{C}$

- Cell culture centrifuge 
- $\mathrm{CO}_{2}$ incubator

- Laminar flow hood

Electrophysiological equipment

- Reverse microscope (Nikon Eclipse TE200) equipped with a fluorescence device

- Borosilicate glass pipettes (Hilgenberg GmbH, Malsfeld)

- Glass pipette puller (Sutter Instruments)

- Micromanipulators (M-UMR 8.25 Newport)

- Piezoelectric driver for nanopositioning (E660, Physics Instruments)

- Analog-to-digital/Digital-to-analog converter (Digidata 1332, Molecular Devices)

- Patch-clamp Amplifier (Axopatch 200B, Molecular Devices)

- Antivibration table

- Faraday cage

- Perfusion system (self made equipped with telecontrolled (Elesystem) electrovalves (Sirai, D301V51)

- 35-mm Petri dish (Greiner bio-one; Cellstar, \#627160)

Reagents

Cell culture reagents

- Dulbecco’s Modified Eagle Medium (DMEM): GIBCO ${ }^{\circledR}, \# 41965$

- Iscove’s Modified Dulbecco’s Medium (IMDM): GIBCO ${ }^{\circledR}, \# 21980$

- KnockOut $^{\mathrm{TM}}$ DMEM: $\mathrm{GIBCO}^{\circledR}, \# 10829$

- Dulbecco's Modified Eagle Medium F-12 Nutrient Mixture (HAM) 1:1 1X (DMEM/F12): $\mathrm{GIBCO}^{\circledR}, \# 21331$

- Dulbecco's Modified Eagle Medium F-12 Nutrient Mixture (HAM) 1:1 1X (DMEM/F12): $\mathrm{GIBCO}^{\circledR}, \# 31330$

- $\quad$ Pluripro ${ }^{\circledR}$ Medium, 500ML: CELL Guidance System, \#MK-01 
- Nutristem ${ }^{\circledR}$ hES XF, contains HSA: Biological Industries, \#05-100-1A

- $\quad$ Pluripro ${ }^{\circledR}$ Matrix: CELL Guidance System, \#M04

- $\quad \mathrm{N}-2$ supplement: GIBCO ${ }^{\circledR}, \# 17502-048$

- $\quad$ B-27 supplement: GIBCO ${ }^{\circledR}, \# 17504-044$

- Bovine serum albumin (BSA): Sigma-Aldrich, \#A4503

- Dimethyl sulfoxide (DMSO): Sigma-Aldrich, \#D2650

- Dulbecco's Phosphate Buffer Saline w/o Calcium and Magnesium (PBS): Euroclone, \#ECB4004L50

- $\quad$ Fetal Bovine Serum: GIBCO ${ }^{\circledR}, \# 1600$

- Foetal Bovine Serum, EU approved: Euroclone, \#ECS0180L

- KnockOut serum ${ }^{\mathrm{TM}}(\mathrm{KSR}): \mathrm{GIBCO}^{\circledR}, \# 10828-028$

- $\quad$ MEM Non Essential Aminoacids 100X (MEM NEAA): GIBCO ${ }^{\circledR}, \# 11140-035$

- Penicillin/Streptomycin 100X: Euroclone \# ECB3001D

- L-Glutamine 100X: Euroclone, \#ECB3000D

- GlutaMAX $^{\mathrm{TM}}$ - I 100X: GIBCO ${ }^{\circledR}, \# 35050-038$

- $\quad \beta$-Mercaptoethanol solution 50 mM: GIBCO ${ }^{\circledR}, \# 31350-010$

- Accutase solution: Millipore, \#SF006

- $\quad 0.5 \%$ Trypsin/EDTA (10X) 100 ml: GIBCO ${ }^{\circledR}, \# 15400-054$

- Collagenase Type IV: GIBCO ${ }^{\circledR}, \# 17104-019$

- $\quad$ Matrigel ${ }^{\mathrm{TM}}: \mathrm{BD}, \# 354234$

- Matrigel $^{\mathrm{TM}}$ reduced factor: $\mathrm{BD}$, \# 356231

- Natural mouse laminin: GIBCO ${ }^{\circledR}$, \# 23017-015

- Poly-D-lysine hydrobromide: Sigma-Aldrich, \#P6407-5MG

- Gelatin from porcine skin, Type A: Sigma-Aldrich, \#G1890-500G

- Recombinant human Fibroblast Growth Factor basic (hFGF-2): R\&D, \#4114TC-01M

- Rock Inhibitor Y-27632: Santa Cruz, \#sc-281642A 
- Dorsomorphin: Sigma-Aldrich, \#P5499-5MG

- SB-431542: TOCRIS, \#1614

- DAPT: Sigma-Aldrich, \#D5942

- Recombinant Mouse Noggin: R \& D, \#1967-NG-025

- Insulin, Human Recombinant, Zinc Solution, 5 ml: GIBCO ${ }^{\circledR}$, \#12585014

- Recombinant mouse Sonic Hedgehog Homolog, N-terminus (SHH C-25II): R\&D, \#464-SH-025

- Recombinant Human Dickkopf-related protein-1 (DKK-1): Peprotech, \#167120300200

- Recombinant Human Brain Derived Neurotrophic Factor (BDNF): Peprotech, \#167450-02-1000

- Trypan Blue Stain 0,4\% 100 ml: GIBCO ${ }^{\circledR}, \# 15250-061$

- Mitomycin C: Sigma-Aldrich, \#M4287-2MG

- Paraformaldheyde: MP Biomedicals, \#150146

- Triton $^{\circledR}$ X-100 Molecular biology grade: Euroclone, \#EMR323500

- PCR Primers (Table 1)

- Antibodies (Table 2)

Electrophysiological reagents

- NBQX 2,3-Dioxo-6-nitro-1,2,3,4-tetrahydrobenzo[f]quinoxaline-7-sulfonamide: TOCRIS, \#1044

- CPP (RS)-3-(2-Carboxypiperazin-4-yl)-propyl-1-phosphonic acid: TOCRIS, \#0173

- TTX Tetrodotoxin: Alomone

- 4-AP: Sigma-Aldrich, \#A0152

- Biocytin free base: Sigma-Aldrich, \#B4261

- Quinpirole (4aR-trans)-4,4a,5,6,7,8,8a,9-Octahydro-5-propyl-1H-pyrazolo[3,4-g]quinoline hydrochloride: TOCRIS, \#1061

- Dopamine 2-(3,4-Dihydroxyphenyl)ethylamine hydrochloride: Sigma-Aldrich, \#H-8502

- (-)-Bicuculline methiodide (5S)-5-[(6R)-6,8-Dihydro-8-oxofuro[3,4-e]-1,3-benzodioxol-6-yl]5,6,7,8-tetrahydro-6,6-dimethyl-1,3-dioxolo[4,5-g]isoquinolinium iodide: Sigma-Aldrich, \#14343 
- Lidocaine n-ethyl bromide or QX-314 N-(2,6 dimethylphenylcarbamoylmethyl) triethylammonium bromide: Sigma-Aldrich, \#L-5783

Solutions

Solutions for cell culture

- Dulbecco's Phosphate Buffer Saline w/o Calcium and Magnesium with antibiotics (PBS): $1 \%$ Penicillin/Streptomycin $100 \mathrm{X}$ solution. Store at $4{ }^{\circ} \mathrm{C}$ for up to 2 weeks.

- PBS-BSA solution: $0.1 \%$ (wt/vol). Add $10 \mathrm{mg}$ BSA to a $100 \mathrm{ml}$ of PBS and filter. Store at $-20{ }^{\circ} \mathrm{C}$ up to 1 year.

- Mitomycin stock solution: add $4 \mathrm{ml}$ of PBS into the vial to obtain a $0.5 \mathrm{mg} / \mathrm{ml}$ solution. Prepare the solution fresh before use, and protect it from light. Store at $4{ }^{\circ} \mathrm{C}$ for up to 2 weeks.

- Gelatin solution: $0.1 \%(\mathrm{wt} / \mathrm{vol})$ gelatin type A from porcine skin in distilled water. Add $500 \mathrm{ml}$ of distilled water to a $500 \mathrm{ml}$ glass bottle containing $0.5 \mathrm{~g}$ gelatin and autoclave. Store at $4{ }^{\circ} \mathrm{C}$ up to 1 year.

- CD1 Medium: DMEM \#41965 supplemented with $10 \%$ FBS (GIBCO), 2 mM non-essential aminoacids (vol/vol), $1 \%$ Penicillin/Streptomycin $100 \mathrm{X}$. Store at $4{ }^{\circ} \mathrm{C}$ for up to 3 weeks.

- FS Medium: IMDM supplemented with $15 \%$ FBS, $1 \%$ Penicillin/Streptomycin 100X. Store at $4{ }^{\circ} \mathrm{C}$ for up to 3 weeks.

- The cell culture media used for the different hPS cell lines are summarized in Note 1.

- Collagenase IV stock solution: resuspend the lyophilized powder in DMEM 31330 adjusting the enzyme concentration to $1 \mathrm{mg} / \mathrm{ml}$, pass it through $0.22 \mu \mathrm{m}$ filter to sterilize. Aliquot and store at -20 ${ }^{\circ} \mathrm{C}$ for up 1 year.

- Matrigel solution: Standarize Matrigel ${ }^{\mathrm{TM}}$ concentration to $5 \mathrm{mg} / \mathrm{ml}$ with DMEM 31330 Medium. Use 1 or $2 \mathrm{ml}$ to cover 35-mm Petri dish and 6-well plates, or 60-mm Petri dish respectively. Move the plate or dish in order to cover perfectly all the bottom area. Incubate $30 \mathrm{~min}$ at $37{ }^{\circ} \mathrm{C}$ or overnight at $4{ }^{\circ} \mathrm{C}$. Eliminate coating matrix solution before use. Be careful: Matrigel ${ }^{\mathrm{TM}}$ polymerizes irreversibly 
at room temperature (RT). Carry out all steps using pre-cooled fungible material at $-20{ }^{\circ} \mathrm{C}$. Prepare before use. Store coated dishes and wells at $4{ }^{\circ} \mathrm{C}$ for up to 1 week.

- Gelatin-coated culture dishes: Cover the bottom of a well plate or a Petri dish with $0.1 \%$ gelatin. Use 1 or $2 \mathrm{ml}$ to cover 35-mm Petri dish and 6-well plates, or 60-mm Petri dish respectively. Move back and forth the plate or dish in order to cover equally all area. Incubate at least $15 \mathrm{~min}$ at $37^{\circ} \mathrm{C}$. Eliminate gelatin solution before use. Prepare before use. Store coated dishes and wells at $4{ }^{\circ} \mathrm{C}$ for up to 1 week.

- Poly-D-Lysine/laminin-coated culture dishes: cover the bottom of a well plate or a Petri dish with Poly-D-Lysine $5 \mu \mathrm{g} / \mathrm{ml} /$ laminin $3 \mu \mathrm{g} / \mathrm{ml}$ solution. Use 1 or $2 \mathrm{ml}$ to cover $35-\mathrm{mm}$ Petri dish and 6well plates, or $60-\mathrm{mm}$ Petri dish respectively. Incubate $2 \mathrm{~h}$ at $37{ }^{\circ} \mathrm{C}$ or overnight at $4{ }^{\circ} \mathrm{C}$. Be careful: Poly-D-Lysine is toxic, wash at least 3 times with PBS $1 \mathrm{X}$ before use. Prepare before use. Store coated dishes and wells at $4{ }^{\circ} \mathrm{C}$ for up to 1 week.

- Conditioned human ES/iPS KSR Medium: Plate feeders on T75 flask in feeder Medium. Next day, rinse with PBS 1X and replace feeder Medium with $20 \mathrm{ml}$ of complete hES/iPS KSR Medium lacking FGF-2. For the next 5 days, collect every day the medium and replace it with $20 \mathrm{ml}$ fresh complete hES/iPS KSR Medium. Filter through $0.22 \mu \mathrm{m}$-sterile filter. Store conditioned Medium at $4{ }^{\circ} \mathrm{C}$ for up to 1 week, or alternatively at -20 or $-80^{\circ} \mathrm{C}$ for long-term storage.

- Rock inhibitor stock solution: reconstitute $\mathrm{Y}-27632$ in distilled $\mathrm{H}_{2} \mathrm{O}$ to $10 \mathrm{mM}$. Store at $-20{ }^{\circ} \mathrm{C}$.

- SB431542 stock solution: reconstitute SB431542 in DMSO to $10 \mathrm{mM}$. Store at $-20^{\circ} \mathrm{C}$.

- Dorsomorphin stock solution: reconstitute Dorsomorphin in DMSO to $5 \mathrm{mM}$. Store at $-20{ }^{\circ} \mathrm{C}$.

- Noggin stock solution: reconstitute recombinant mouse Noggin in PBS-BSA 0,1\% to $100 \mu \mathrm{g} / \mathrm{ml}$. Store at $-20{ }^{\circ} \mathrm{C}$.

- DKK-1 stock solution: reconstitute DKK-1 in PBS-BSA 0,1\% to $10 \mu \mathrm{g} / \mathrm{ml}$. Store at $-20{ }^{\circ} \mathrm{C}$.

- SHH C25II stock solution: reconstitute SHH C25II in PBS-BSA $0,1 \%$ to $100 \mu \mathrm{g} / \mathrm{ml}$. Store at $-20{ }^{\circ} \mathrm{C}$.

- BDNF stock solution: reconstitute BDNF in PBS-BSA $0,1 \%$ to $10 \mu \mathrm{g} / \mathrm{ml}$. Store at $-20^{\circ} \mathrm{C}$.

- $\quad$ N2 Medium: DMEM/F12 supplemented with N2 100X, insulin $20 \mu \mathrm{g} / \mathrm{ml}$. 
- Day 0-5 Medium: hES/h-iPS KSR Medium supplemented with Dorsomorphin $5 \mu \mathrm{M}$ (or noggin 500 $\mathrm{ng} / \mathrm{ml})$ and SB431542 $10 \mu \mathrm{M}$.

- Day 5-7 Medium: $75 \%$ hES/iPS KSR Medium + $25 \%$ N2 Medium supplemented with Dorsomorphin $5 \mu \mathrm{M}$, SB431542 $10 \mu \mathrm{M}$, SHH C-25II 200 ng/ml, DKK-1 100 ng/ml.

- Day 7-9 Medium: $50 \%$ hES/iPS Medium + $50 \%$ N2 Medium supplemented with Dorsomorphin 5 $\mu \mathrm{M}, \mathrm{SB} 43154210 \mu \mathrm{M}$, SHH C-25II 200 ng/ml, DKK-1 100 ng/ml.

- Day 9-11 Medium: $25 \%$ hES/iPS Medium + $75 \%$ N2 Medium supplemented with Dorsomorphin 5 $\mu \mathrm{M}, \mathrm{SB} 43154210 \mu \mathrm{M}$, SHH C-25II $200 \mathrm{ng} / \mathrm{ml}$, DKK-1 $100 \mathrm{ng} / \mathrm{ml}$.

- Day 12-15 Medium: N2 Medium supplemented with SHH C-25II 200 ng/ml, DKK-1 100 ng/ml.

- $\mathrm{NBB}_{30}$ Medium: N2 Medium supplemented with B27 (1:50), BDNF 30 ng/ml, SHH C-25II 200 ng/ml, DKK-1 100 ng/ml.

- $\quad \mathrm{NBB}_{50}$ Medium: N2 Medium supplemented with B27 (1:50), BDNF $50 \mathrm{ng} / \mathrm{ml}$.

- Formaldheyde $20 \%$ solution: Combine $20 \mathrm{~g}$ of paraformaldehyde and $100 \mathrm{ml}$ of $\mathrm{H}_{2} \mathrm{O}$, add $20 \mu \mathrm{l}$ $\mathrm{NaOH} 10 \mathrm{~N}$. Heat at $58^{\circ} \mathrm{C}$ mixing in a chemical fume hood. Store as $45 \mathrm{ml}$ aliquots at $-20^{\circ} \mathrm{C}$.

- Formaldheyde $4 \%$ solution: dilute $45 \mathrm{ml}$ formaldheyde $20 \%$ solution in $180 \mathrm{ml}$ PBS $1 \mathrm{X}$ (final concentration) and filter.

- Pearmeabilization solution: $0.5 \%$ (vol/vol) Triton X-100 in PBS.

- Blocking solution: $5 \%$ fetal bovine serum, $0.3 \%$ (vol/vol) Triton X-100 in PBS.

- Primary antibody solution: $3 \%$ fetal bovine serum, $0.2 \%$ (vol/vol) Triton X-100 - PBS added with the appropriate volume of primary antibody.

- Secondary antibody solution: $3 \%$ fetal bovine serum, $0.2 \%$ (vol/vol) Triton X-100 - PBS added with secondary antibody and Hoechst.

Solutions for electrophysiology

- NBQX, an elective blockers of $\alpha$-amino-3-hydroxy-5-methyl-4-isoxazolepropionic acid (AMPA) receptors; stored in $50 \mu \mathrm{l}$ aliquots $(5 \mathrm{mM})$ at $-20^{\circ} \mathrm{C}$. Dilute in the external solution to a final concentration of $10 \mu \mathrm{M}$. 
- $\mathrm{CPP}$, potent NMDAR antagonist; prepared a $5 \mathrm{mM}$ stock in distilled water and stored at $-20^{\circ} \mathrm{C}$.

Dilute in the external solution to a final concentration of $30 \mu \mathrm{M}$.

- TTX, prepared a $300 \mathrm{mM}$ stock in distilled water and stored in $34 \mu 1$ aliquots at $-20{ }^{\circ} \mathrm{C}$. Dilute in the external solution to a final concentration of $1 \mu \mathrm{M}$.

- 4-AP, freshly added to the external solution at a final concentration of $1 \mathrm{mM}$.

- Biocytin free base, freshly added into the intracellular solution (1\%).

- Quinpirole, a selective dopamine D2 receptor agonist; prepared a $5 \mathrm{mM}$ stock in distilled water and stored at $-20{ }^{\circ} \mathrm{C}$. Dilute in the external solution to a final concentration of $5 \mu \mathrm{M}$.

- Dopamine 2-(3,4-Dihydroxyphenyl)ethylamine hydrochloride, prepared at $500 \mathrm{mM}$ stock in distilled water and stored at $-20{ }^{\circ} \mathrm{C}$. Dilute in the external solution to a final concentration of $100 \mu \mathrm{M}$

- (-)-Bicuculline methiodide (5S)-5-[(6R)-6,8-Dihydro-8-oxofuro[3,4-e]-1,3-benzodioxol-6-yl]5,6,7,8-tetrahydro-6,6-dimethyl-1,3-dioxolo[4,5-g]isoquinolinium iodide, a selective antagonist of $\mathrm{GABA}_{\mathrm{A}}$ receptors; prepared a $5 \mathrm{mM}$ stock in distilled water and stored in $500 \mu$ aliquots at $-20{ }^{\circ} \mathrm{C}$. Dilute in the external solution to a final concentration of $10 \mu \mathrm{M}$.

- For $\mathrm{Na}^{+}$- and $\mathrm{K}^{+}$-currents and firing characterization.

Intracellular: solution 1 (Table 3)

Extracellular: solution 2 (Table 3)

- For isolated $\mathrm{K}^{+}$-currents

Intracellular: solution 5 (Table 3)

Extracellular: solution 4 (Table 3)

- For spontaneous and pharmacologically-evoked GABAergic currents

Intracellular: solution 3 (Table 3)

Extracellular: solution 2 (Table 3)

\section{Methods}

Protocol A. Preparation of the cultures of hPS cells 
Here we describe the routine culture of hES cells and fibroblasts-derived hiPS cells. In our striatal differentiation protocol we employed hES/iPS cells cultured either on feeder cells or on Matrigel in feederfree condition (see Note 1). We have successfully used our protocol to differentiate the H9 hES cell line cultured on MEF CD1 strain or on Matrigel, the HS401 hES cell line cultured on foreskin FS human feeder cells, the DF3F hiPS cell line cultured on MEF CD1 strain (as described in Camnasio et al., 2012 [13] where it is named WT-iPS $3 \mathrm{~F}-1)$.

\section{Culture of hPS cells on feeder cells}

1. Thaw a vial of feeders (CD1 or FS) in a $37^{\circ} \mathrm{C}$ water bath.

2. Resuspend the cells in $10 \mathrm{ml}$ of appropriate feeder medium at room temperature (RT) $\left(18-22^{\circ} \mathrm{C}\right)$.

3. Spin for $3 \mathrm{~min}$ at $200 \mathrm{~g}$ at RT.

4. Resuspend in $14 \mathrm{ml}$ of appropriate feeder medium and transfer the cells into a T75 flask. Culture the cells overnight at $37^{\circ} \mathrm{C}$ in $5 \% \mathrm{CO}_{2}$ incubator.

5. On the following day, replace feeder medium supplemented with $50 \mu \mathrm{g} / \mathrm{ml}$ of mytomicin $\mathrm{C}$ and incubate the cells for three $\mathrm{h}$ at $37^{\circ} \mathrm{C}$ in a $5 \% \mathrm{CO}_{2}$ incubator.

6. At the end of the incubation remove the feeder medium and rinse the feeders twice with $37^{\circ} \mathrm{C}$ PBS $1 X$.

7. Add Trypsin $1 \mathrm{X}$ and incubate the cells for $5 \mathrm{~min}$ at $37^{\circ} \mathrm{C}$ in a $5 \% \mathrm{CO}_{2}$ incubator. Inactivate Trypsin by adding 4 volumes of medium containing fetal bovine serum and spin for $3 \mathrm{~min}$ at $200 \mathrm{~g}$ at RT.

8. Remove and discard the supernatant and resuspend the pellet in $3 \mathrm{ml}$ of feeder medium. Count resuspended viable cells with trypan blue stain and seed viable cells in gelatin-coated wells of 6-well plate $\left(2.6 \times 10^{5}\right.$ cells $/ \mathrm{cm}^{2} \mathrm{CD} 1 \mathrm{MEFs}, 3.3 \times 10^{5} \mathrm{cells} / \mathrm{cm}^{2} \mathrm{FS}$ cells $)$.

9. On the following day, remove the feeder medium and rinse the feeder cells once with $37^{\circ} \mathrm{C}$ PBS $1 \mathrm{X}$.

10. Add $2 \mathrm{ml}$ of KSR medium (appropriate medium for the employed lines, see Note 1) that contains 10 $\mu \mathrm{M} \mathrm{Y}-27632$ and $10 \mathrm{ng} / \mathrm{ml} \mathrm{FGF-2,} \mathrm{to} \mathrm{one} \mathrm{well} \mathrm{of} \mathrm{6-well} \mathrm{plate} \mathrm{and} \mathrm{let} \mathrm{the} \mathrm{cells} 1.5 \mathrm{~h}$ at $37^{\circ} \mathrm{C}$ in a $5 \%$ $\mathrm{CO}_{2}$ incubator. 
11. Partially thaw a vial of frozen hPS cells in a $37{ }^{\circ} \mathrm{C}$ water bath.

12. Transfer the partially thawed hPS cells to 10 volumes of appropriate KSR medium at RT.

13. Centrifuge the cells once at $100 \mathrm{~g}$ for $3 \mathrm{~min}$ at RT.

14. Wash once more by repeating steps 12 and 13 .

15. Gently resuspend the cells in $100 \mu \mathrm{l}$ of appropriate KSR medium, and then plate the cells in solution into the feeder-coated well containing appropriate KSR medium with $10 \mu \mathrm{M}$ Y-27632 and $10 \mathrm{ng} / \mathrm{ml}$ FGF-2, as indicated in step 10 . Culture overnight at $37^{\circ} \mathrm{C}$ in $5 \% \mathrm{CO} 2$.

16. On the next day, replace the medium with fresh and appropriate KSR medium containing $10 \mathrm{ng} / \mathrm{ml}$ FGF-2 but lacking Y-27632. Change the medium every day until hPS cell colonies are $\sim 1 \mathrm{~mm}$ in diameter and can be seen with the naked eye. Depending on the cell line, this can take between 5 and 7 days.

17. Once visible colonies appear, passage the hPS cell colonies with collagenase IV. Remove KSR medium and add $1 \mathrm{ml}$ of $37^{\circ} \mathrm{C}$ collagenase IV solution to the hPS cell cultures.

18. Incubate at $37^{\circ} \mathrm{C}$ in $5 \% \mathrm{CO}_{2}$ for up to $45 \mathrm{~min}$. Check every $10 \mathrm{~min}$ on an inverted microscope for detachment of colonies from the underlying feeder cells.

19. When the colonies are detached from the feeder layer, transfer the medium containing the colonies into a 15-ml Falcon tube, avoiding triturating the colonies.

20. Pellet the colonies by spinning for $3 \mathrm{~min}$ at $100 \mathrm{~g}$ at RT. Remove and discard the supernatant.

21. Resuspend the colonies in $2 \mathrm{ml}$ of appropriate KSR medium added with $10 \mu \mathrm{M}$ Y-27632 and 10 ng/ml FGF-2, and pipette up and down 5 or 6 times with a P1000 pipette to break the colonies into fragments containing 50 to 100 cells.

22. Plate the fragmented hPS cell colonies at a ratio of 1:6 (relative to the original number of culture dishes) into fresh feeder-coated dishes in appropriate KSR medium with $10 \mathrm{ng} / \mathrm{ml} \mathrm{FGF-2.} \mathrm{Make} \mathrm{sure}$ that the colony fragments are distributed evenly on the plate.

23. Continue to incubate the cells and change the medium every day until the hPS cell colonies are $\sim 1$ $\mathrm{mm}$ in diameter and are visible with the naked eye. Continue as from step 17 until sufficient expansion of the hPS cultures is obtained. 


\section{Culture of hPS cells on Matrigel in feeder-conditioned medium (feeder-CM)}

a) Preparation of KSR-conditioned medium (feeder-CM):

We used different feeder cell types or strains to condition KSR medium depending on the hPS cell line employed. We used CD1 MEFs for H9 and hiPS DF3F cells, and FS for HS401 cell line.

24. Repeat the steps from 1 to 8 , by plating $2.2 \times 10^{6}$ mitomycin C-treated cells in a T75 flask gelatincoated in appropriate feeder medium.

25. The following day, replace the feeder medium with $30 \mathrm{ml}$ of KSR-medium.

26. Collect the KSR medium, now considered feeder-CM, from the flasks after $3 \mathrm{~h}$ of conditioning. If the medium is conditioned overnight, dilute it 1:2 with fresh KSR medium.

27. Each day, filter the collected feeder-CM with a $0.22 \mu \mathrm{M}$ filter. Filtered feeder-CM can be stored at 20 or $-80^{\circ} \mathrm{C}$ up to six months, until use.

28. At the time of use, thaw the $\mathrm{CM}$ in a $37^{\circ} \mathrm{C}$ waterbath, and supplement it with $10 \mathrm{ng} / \mathrm{ml} \mathrm{FGF-2.}$

b) Plating of hES cells cultured on Matrigel in feeder-CM

29. Plate hPS cells at a density of $0.75 \times 10^{6}$ cells $/ \mathrm{cm}^{2}$ onto $60-\mathrm{mm}$ dishes in feeder-CM $(3 \mathrm{ml} / 60-\mathrm{mm}$ dish) on dishes coated with Matrigel substrate.

30. Culture cells for 5 to 7 days at $37^{\circ} \mathrm{C}$ in $5 \% \mathrm{CO}_{2}$.

31. When the cells have reached $\sim 90 \%$ of confluence, add $1.5 \mathrm{ml}$ of Accutase, and leave the cells at $37^{\circ} \mathrm{C}, 5 \% \mathrm{CO}_{2}$ for $15 \mathrm{~min}$. Check every $5 \mathrm{~min}$ for the detachment of the cells.

32. Dilute the Accutase with 4 volumes of $37^{\circ} \mathrm{C}$ PBS $1 \mathrm{X}$, collect the cells and spin 3 min at $100 \mathrm{~g}$ at RT.

33. Carefully aspirate the supernatant and pipette up and down 5 or 6 times with a P1000 pipette to break the cell pieces into a single cell suspension. 
34. Plate the cells at a ratio of 1:3 (relative to the original number of culture dishes) in an appropriate volume of feeder-CM (previously prepared) supplemented with $10 \mathrm{ng} / \mathrm{ml}$ FGF-2 and Y-27632 10 $\mu \mathrm{M}$, on freshly Matrigel-coated dishes.

35. On the next day, replace the medium with fresh feeder-CM containing $10 \mathrm{ng} / \mathrm{ml} \mathrm{FGF-2} \mathrm{but} \mathrm{lacking}$ Y-27632. From this step, continue to incubate the cells, by changing the medium every day until cells are confluent. Depending on the cell line, this can take between 5 and 7 days.

\section{Protocol B. Striatal differentiation procedure}

In this section we describe our ontogeny-recapitulating protocol for the direct differentiation of hPS cells towards striatal MSNs [9]. This is a multistep procedure composed of three different phases (Fig. 1):

B1. Grooming and preparation of hPS cells, where pluripotent stem cells are plated for neuronal differentiation.

B2. Neural induction and patterning, where the cells lose pluripotency features and acquire neuroectodermal identity expressing PAX6, nestin and SOX1. In this phase the emerging neuroepithelial progenitors are patterned towards a ventral telencephalic fate, and are positive for the expression of OTX2, FOXG1 and GSX2.

B3. Terminal differentiation, when committed striatal progenitors mature towards fully functional MSNs. Starting from day 45 of differentiation, the cells express MAP2, GABA, GAD65/67, calbindin, FOXP1, FOXP2, CTIP2 and DARPP-32. After 80 days of differentiation, 20\% of MAP2 ${ }^{+}$neurons coexpress DARPP-32 and CTIP2. At this stage, neurons are electrophysiologically active and show a pattern of response to stimulation typical of striatal neurons.

\section{B1. Grooming and preparation of hPS cells (from day -3 to day 0 )}


36. It is fundamental to start the differentiation with healthy, pluripotent cells. Inspect cultures for spontaneously differentiated colonies (or cells) and remove them using a P200 pipette. Differentiated colonies typically show loss of defined edges.

37. To begin differentiation, detach hPS cells from feeder cells by addition of Accutase and proceed as described in steps $31-33$

38. To help eliminating the contaminating feeder cells, plate the cell suspension on a gelatin-coated dish $(0.1 \%)$ for $20 \mathrm{~min}$ in feeder-CM added with $10 \mathrm{ng} / \mathrm{ml} \mathrm{FGF-2} \mathrm{and} 10 \mu \mathrm{M} \mathrm{Y}-27632$, by monitoring every 5 min the selective attachment of feeder cells but not of the hPS cells. Keep the cells in 4 $\mathrm{ml} / 60$-mm dish. If hPS cells are grown on Matrigel, skip this step.

39. Collect the cell suspension and spin $3 \mathrm{~min}$ at $100 \mathrm{~g}$ at RT.

40. Carefully aspirate the supernatant and resuspend the pellet in $2 \mathrm{ml}$ of feeder-CM added with 10 ng/ml FGF-2 and $10 \mu \mathrm{M}$ Y-27632. Count resuspended viable cells with trypan blue and seed viable cells at a density of $0.7 \mathrm{X} 10^{5}$ cells $/ \mathrm{cm}^{2}$ on pre-coated Matrigel dishes (see Note 2).

41. Ensure that the cells are evenly distributed in the dishes. Allow the cells to attach overnight at $37^{\circ} \mathrm{C}$ in $5 \% \mathrm{CO}_{2}$ incubator.

42. Check the cells on the day after plating (day -2).

43. Change the medium every day with feeder-CM containing $10 \mathrm{ng} / \mathrm{ml}$ FGF-2 until they reach $90 \%$ confluence, at which point the medium should be switched to neural induction medium.

B2. Neural induction (from day 0 to day 12 ) and patterning (from day 5 to day 26)

44. Day 0: when cells have reached $\sim 90 \%$ confluence (Fig. 2a), add $2 \mathrm{ml}$ (for a well of a 6-well plate, 3 $\mathrm{ml}$ for a $60 \mathrm{~mm}$-dish) of KSR medium + noggin $500 \mathrm{ng} / \mathrm{ml}$ (alternatively use dorsomorphin $5 \mu \mathrm{M}$ instead of noggin during the neural induction step) + SB431542 $10 \mu \mathrm{M}$.

45. Day 3: carefully aspirate the medium and replace it entirely with KSR Medium + noggin $500 \mathrm{ng} / \mathrm{ml}+$ SB431542 $10 \mu \mathrm{M}$ (Day 3-5 Medium). 
46. Day 5: carefully aspirate the medium and replace it entirely with $75 \% \mathrm{KSR}+25 \% \mathrm{~N} 2$ Medium + noggin $500 \mathrm{ng} / \mathrm{ml}+\mathrm{SB} 43154210 \mu \mathrm{M}$. Starting from this day add SHH C-25II $200 \mathrm{ng} / \mathrm{ml}+\mathrm{DKK}-1$ $100 \mathrm{ng} / \mathrm{ml}$ (Day 5-7 Medium).

47. Day 7: carefully aspirate the medium and replace it entirely with $50 \% \mathrm{KSR}+50 \%$ N2 Medium + noggin $500 \mathrm{ng} / \mathrm{ml}+\mathrm{SB} 43154210 \mu \mathrm{M}+\mathrm{SHH}$ C-25II 200ng/ml + DKK-1 100 ng/ml (Day 7-9 Medium).

48. Day 9: carefully aspirate the medium and replace it entirely with $25 \%$ KSR medium $+75 \%$ N2 Medium + noggin 500 ng/ml + SB431542 $10 \mu \mathrm{M}+$ SHH C-25II 200 ng/ml + DKK-1 100 ng/ml (Day 9-11 Medium).

49. Day 12: carefully aspirate the medium and replace it entirely with $100 \%$ N2 Medium + SHH C-25II 200 ng/ml + DKK-1 100 ng/ml (Day 12-15 Medium) (see Note 3).

50. Between day 12 and day 15 , partially change the medium once. Keep 1/3 of medium and add 2/3 of fresh medium composed of 100\% N2 medium + SHH C-25II $200 \mathrm{ng} / \mathrm{ml}+$ DKK-1 $100 \mathrm{ng} / \mathrm{ml}$. The morphogens SHH C-25II (200 ng/ml) and DKK-1 (100 ng/ml) are maintained until day 26.

\section{Rosette replating}

51. Between days 12 and 15, fields full of rosettes become morphologically visible (Fig. 2b, c). To allow the cells to terminally differentiate, they need to be replated. Add $37^{\circ} \mathrm{C}$ Accutase and incubate at $37^{\circ} \mathrm{C}$ in $5 \% \mathrm{CO}_{2}$ for $15-20 \mathrm{~min}$. Check every $5 \mathrm{~min}$ the detaching of the cells. To facilitate clump dissociation, gently shake the dish without pipetting, to avoid excessive cell death.

52. Dilute the Accutase with 4 volumes of PBS $1 \mathrm{X}$ pre-warmed at $37^{\circ} \mathrm{C}$.

53. Collect the cells and spin $3 \mathrm{~min}$ at $200 \mathrm{~g}$ at $\mathrm{RT}$ and resuspend the pellet in $0.5 \mathrm{ml}$ of $\mathrm{NBB}_{30}$ medium supplemented with Y-27632 $10 \mu \mathrm{M}$.

54. Count resuspended viable cells with trypan blue. It is advisable to make an intermediate dilution before counting because of the high cell density.

55. Prepare Matrigel-coated dishes by carefully aspirating all liquid from the dish, taking care not to 
touch the surface (alternatively use poly-D-lysine/laminin-coated dish).

56. Plate $0.65 \times 10^{5}$ cells $/ \mathrm{cm}^{2}$ in a single drop of $40-50 \mu 1$ into a well of a 12 -well plate. Wait at maximum 15 min to allow the cells to adhere and then add $300 \mu$ lof $\mathrm{NBB}_{30}$ medium supplemented with Y$2763210 \mu \mathrm{M}(0.2 \mathrm{ml}$ for well of 24-well plate, $1 \mathrm{ml}$ for well of 6-well plate).

57. Transfer dishes carefully in a $37^{\circ} \mathrm{C}, 5 \% \mathrm{CO}_{2}$ incubator and leave overnight (see Note 4).

58. The day after, check that cells have attached and add $\mathrm{NBB}_{30}$ medium to a final volume of $1 \mathrm{ml}$ per well for a 12-well plate (or $0.5 \mathrm{ml}$ for a well of a 24 -well plate, $2 \mathrm{ml}$ for a well of a 6-well plate). For the amount of morphogens to be added consider the final volume, including the medium present since the day before.

59. Replace the medium every 3 days with partially fresh medium (keep $1 / 3$ of medium and add $2 / 3$ of fresh medium composed of 100\% NBB $_{30}$ medium + SHH C-25II $200 \mathrm{ng} / \mathrm{ml}+\mathrm{DKK}-1100 \mathrm{ng} / \mathrm{ml}$ ) until day 26 (see Note 5).

\section{B3. Terminal differentiation (day 26 to day 80 )}

60. From day 26 to day 80 replace the medium every 3 days with partially fresh medium (keep 1/3 of medium and add $2 / 3$ of fresh $\mathrm{NBB}_{50}$ medium).

61. Stop cultures at 45, 60, 80 days for immunodetection analyses and electrophysiological recordings.

\section{Protocol C. Assays used to monitor progression toward a definitive MSN identity}

During differentiation several classes of neural progenitor/precursor cells arise which eventually give rise to fully differentiated mature neurons. The identity and proportions of these neuronal subclasses can be defined by the combinatorial expression of a core set of TFs and diagnostic markers combined with electrophysiological measurements.

We have identified time points during differentiation allowing to monitor the progression of the cultures towards MSN generation: 
62. Day 5-15, from pluripotency to neuropotency. During this transition neuroectodermal and neuroepithelial cells begin to appear. The first marker to appear at day 5 is PAX6 with $65 \%$ of the cells becoming positive at day 15, when also SOX1 is expressed (Fig. 2b, c and d, Table 1 and 2). At day 15 several rosettes markers such as DACHI, LIXI, LMO3 and MSXI are also detected by RTPCR (Table 1). During this transition, OTX2 is maintained throughout while OCT4 is no longer detected at day 15 (Table 1 and 2).

63. Day 15, emergence of markers of telencephalic and ventral fate. Rosette-stage telencephalic neural progenitors appear at around 15-20 days of differentiation and can be recognized by the expression of FOXG1 (Fig. 2e, Table 1 and 2) and of the LGE marker GSX2 (Fig. 2f, Table 2). 58\% of the cells express the telencephalic markers FOXG1 while 64\% express the ventral telencephalic TF GSX2. At the same time point expression of DLX5, DLX6 and ISLI was found by RT-PCR (Table 1).

64. Day 45, acquisition of a striatal identity. At this time point we revealed the acquisition of a striatal identity that is verified by the presence of a combination of diagnostic postmitotic striatal markers. Starting from this time point the cells show expression of mature neuronal proteins such as MAP2 and TAU, GABAergic markers such as GAD65/67 and GABA, striatal associated markers such as calbindin, FOXP1, FOXP2, CTIP2, ARPP-21 and DARPP-32 (Fig. 3a-f, Table 1 and Table 2). We suggest measuring the co-expression of these markers in the presumptive MSN in order to define the definitive striatal character of a neuron (Fig. 3g, Table 2 and see Note 6). DARPP-32 expression alone is in fact not diagnostic of human MSNs since DARPP- $32^{+}$neurons are found also outside the striatum. We suggest verifying the co-expression of at least GABA/DARPP-32, GAD65-67/DARPP32, CTIP2/DARPP-32, FOXP1/CTIP2 in order to quantify the percentage of MSNs generated at the end of differentiation.

65. Day 80, MSN antigenic maturation achieved. Categorization of the cell types present in the culture at this time point has led to the following numbers: $51 \%$ of cells are MAP2 ${ }^{+}$neurons; about $80 \%$ of the total cells are $\beta$ III-tubulin ${ }^{+}$and $17 \%$ of them are double positive for nestin. Only $7 \%$ of the total cells were pure nestin ${ }^{+}$progenitors. With respect to the $\mathrm{MAP}^{+}$neurons, $78 \%$ were $\mathrm{GABA}^{+}, 60.3 \%$ $\mathrm{CTIP}^{+}\left(86 \%\right.$ of which co-expressed GABA) and $53 \%$ calbindin $^{+}$neurons. $70.6 \%$ of the calbindin ${ }^{+}$ 
neurons co-expressed CTIP2, thus confirming the general acquisition of an MSN fate and not of an interneuron identity. An estimated 20\% of the neurons were immunopositive for DARPP-32 (10\% if the total number of cells in the dish is considered), whose MSN identity is confirmed by the coexpression with CTIP2 (Fig. 3 a-g).

Striatal interneurons at day 80 are represented by $<15.7 \%$ of the cells that are calbindin ${ }^{+} /$CTIP2suggesting their non-MSN striatal identity. Approximately $9.8 \%$ of the cells were calretinin ${ }^{+}$. A few somatostatin ${ }^{+}$interneurons, but no neuropeptide $\mathrm{Y}^{+}$, parvalbumin ${ }^{+}$, or choline O-acetyltransferase $(\mathrm{ChAT})^{+}$interneurons were found (Table 2).

66. Day 80, MSN functional maturation achieved. As a further proof of maturation, typical repetitive firing patterns and electrophysiological membrane properties can be detected in biocytin-injected DARPP-32+ MSNs (Fig. 4a, b). The presence of GABA-evoked currents, $I_{A}$ potassium current (Fig. 4c, d) and dopamine neuromodulation (as described in our original report Delli Carri et al. 2013 [9]) will further ascertain the electrophysiological signature of GABAergic striatal projection neurons (see below).

\section{Immunofluorescence analysis to investigate cell identity}

67. Fix cells in culture in fresh $4 \%$ (wt/vol) formaldehyde for $10 \mathrm{~min}$ at RT. Remove the formaldehyde.

68. Perform two 5-min washes with PBSX [0.1\% (vol/vol) Triton X-100-PBS 1X] and permeabilize the cells 10 min with $0.3 \%$ (vol/vol) Triton X-100 in PBS 1X.

69. Perform antigen unmasking when required (see Note 7).

70. Block for $1 \mathrm{~h}$ with blocking solution.

71. Incubate with primary antibodies (Table 2) diluted in primary blocking solution at $4{ }^{\circ} \mathrm{C}$ overnight.

72. After three washes with PBS $1 \mathrm{X}$, incubate for $1 \mathrm{~h}$ at RT with the appropriate secondary antibody and counterstain the nuclei with Hoechst, diluted in the secondary antibody solution (Table 2).

73. After three washes with PBS $1 \mathrm{X}$ and mounting proceed with the co-localization studies with in vivo validated antibodies as reported in Table 2 and described in Delli Carri et al. (2013) [9] (see Note 6). 


\section{Electrophysiological characterization of striatal MSNs derived from hPS cells}

The active and passive intrinsic properties of the developing hPS cell-derived MSNs and their spontaneous and pharmacologically-evoked synaptic currents are obtained using the whole-cell patch-clamp technique both in voltage- and current-clamp mode. To monitor the electrophysiological differentiation of the neurons, the recordings are repeated at intermediate time points and at the end of the differentiation process. The MSN phenotype of the recorded cells can be confirmed by the co-detection of the biocytin (intracellularly injected through the patch-clamp pipette during recording) and the expression of DARPP-32 or CTIP2 in the same cells.

74. Before recordings: a) the extracellular solution (Solution 2, Table 3) should be kept at room temperature for at least $30 \mathrm{~min}$. Biocytin (1\%), $\mathrm{Na}_{2}-\mathrm{ATP}$, Creatine phosphate and $\mathrm{Na}_{3}-\mathrm{GTP}$ should be freshly added to the intracellular solution immediately before the beginning of the experiments. $b$ ) A set of borosilicate glass pipettes can be prepared using a puller. When filled with the intracellular solution the pipette resistance should range between 3,5 and $4 \mathrm{M} \Omega$. C) The perfusion system should be filled with specific solutions and drugs and the functionality of the electrovalves checked.

75. $2.5 \mathrm{ml}$ of the external solution (Solution 2, Table 3) is added to a 35-mm Petri dish.

76. By taking two sterilized fine-shaped tweezers, the glass coverslip plated with cells is removed from the culture medium and gently laid on the bottom of the Petri dish.

77. The tip of the perfusion system is positioned near the recording field.

78. The pipettes are filled with the $0.45 \mu \mathrm{m}$ filtered intracellular solution (Solution 1, Table 3).

79. Following giga-seal and whole cell configuration, a $-10 \mathrm{mV}$ step protocol should be applied. The integration of the capacitive current is used to determine the membrane capacitance and is performed with the software Clampfit (Molecular Devices).

80. Capacitance compensation and series resistance correction should be performed.

81. In voltage-clamp mode a protocol is run to detect the presence of $\mathrm{Na}^{+}$and delayed-rectifier $\mathrm{K}^{+}$ currents by holding the membrane potential at $-90 \mathrm{mV}$ and giving a series of progressively increasing test steps from $-80 \mathrm{mV}$ to $+40 \mathrm{mV}$. 
82. To record the resting membrane potential the system should be switched to the current-clamp mode. To characterize the voltage response and the firing properties, maintaining the current-clamp configuration, a series of sub- and suprathreshold depolarizing and hyperpolarizing steps of current (duration 1 or $3 \mathrm{sec}$ ) are applied from a membrane potential of $-80 /-70 \mathrm{mV}$. A delay in the first spike generation would suggest the presence of the $I_{A}$ potassium current that will be verified by applying 4-AP $(1 \mathrm{mM})$, a selective blocker of A-type $\mathrm{K}^{+}$channels, and determine a shortening time in the generation of the first spike. Dopaminergic modulation of membrane potential through D2 receptors should be checked for by applying the selective agonist (quinpirole, $5 \mu \mathrm{M}$ ).

83. Delayed rectifier and fast potassium currents can be checked for. Steps from 68 to 74 should be repeated and tetrodotoxin (TTX $1 \mu \mathrm{M}$ ) added to the extracellular solution (Solution 4, Table 3). Here is the protocol: following holding the membrane potential at $-110 \mathrm{mV}$ for $1 \mathrm{sec}$, tests potentials should be applied between -70 to $+40 \mathrm{mV}$ (step size $10 \mathrm{mV}$ ). The fast inactivating transient $\left(\mathrm{I}_{\mathrm{A}}\right) \mathrm{K}^{+}$ current is completely abolished when the test potential is preceded by a $50 \mathrm{~ms}$ prepulse at $-40 \mathrm{mV}$ or when the extracellular solution is supplied with 4-AP $(1 \mathrm{mM})$. Under these conditions, only the slow delayed rectifier $\mathrm{K}^{+}$current component could be elicited. The fast inactivating $\mathrm{K}^{+}$current could be isolated by subtracting the traces recorded after the prepulse to $-40 \mathrm{mV}$ or during 4-AP perfusion from those elicited in normal conditions.

84. GABAergic synaptic currents, spontaneously evoked and pharmacologically-elicited by locally applying GABA $(20 \mu \mathrm{M})$ should be checked for. Repeat step from 68. to 74 . The extracellular solution (Solution 2, Table 3) is added with CNQX $(10 \mu \mathrm{M})$ and CPP $(30 \mu \mathrm{M})$ to block AMPA and NMDA receptors respectively. Due to the photosensitivity of CNQX, these experiments should be performed at very low environmental light intensity. The intracellular solution (Solution 1, Table 3) should contain lidocaine (QX314, $\mu \mathrm{M})$ to block, intracellularly, the $\mathrm{Na}^{+}$channels. A possible modulatory effect of dopamine on GABA-elicited currents can be checked for by applying dopamine $(100 \mu \mathrm{M})$. 
85. At the end of the electrophysiological recordings the extracellular solution can be carefully removed from the Petri dish and fixed for immunofluorescence reaction. The recorded cells will be identified with streptavidin-conjugated to fluorochrome and visualized using a confocal microscopy.

\section{Notes}

\section{Note 1.}

The table lists the different media used for the culture of the hPS cell lines employed in this work.

\begin{tabular}{|c|c|c|c|}
\hline hPS cell line & H9 & HS401 & iPS (DF3F) \\
\hline Feeder cells & MEF CD1 & Human foreskin (FS) & MEF CD1 \\
\hline $\begin{array}{c}\text { Alternative } \\
\text { substrates verified } \\
\text { with feeder-CM }\end{array}$ & $\begin{array}{c}\text { Matrigel or } \\
\text { Pluripro }{ }^{\circledR} \text { Matrix } \\
\text { (with Nutristem or } \\
\text { Pluripro medium) }\end{array}$ & - & - \\
\hline KSR medium & $\begin{array}{c}\text { DMEM/F12 } \\
\# 31330 \\
\text { supplemented with } \\
20 \% \text { KnockOut } \\
\text { serum }^{\mathrm{TM}}(\mathrm{vol} / \mathrm{vol})\end{array}$ & $\begin{array}{l}\text { KO-DMEM } \\
\text { supplemented with } \\
\text { 20\% KnockOut } \\
\text { serum }^{\mathrm{TM}}\end{array}$ & $\begin{array}{c}\text { DMEM/F12 } \\
\# 31330 \\
\text { supplemented with } \\
\text { 20\% KnockOut } \\
\text { serum }^{\mathrm{TM}}(\mathrm{vol} / \mathrm{vol})\end{array}$ \\
\hline
\end{tabular}

\section{Note 2.}

We have tested several substrates for the neural induction phase:

(i) Laminin $(10 \mu \mathrm{g} / \mathrm{ml})$ : the cells remain poorly attached until day 12 , usually they detach before day 9 .

(ii) Poly-D-lysine: on this substrate the hPS cells we have tested do not proliferate nor reach a good confluence necessary for neural induction but rather degenerate soon after plating.

(iii) Poly-ornithine: also in this case, we noticed that cells detach at around day 5. 
(iv) As an alternative we plate cells on Matrigel reduced factors-coated dishes.

\section{Note 3.}

As an alternative, it is possible to use the same medium from day 0 to day 12 composed of: DMEM/F12 \#21331, N-2 1:100, B-27 1:100, insulin $20 \mathrm{ng} / \mathrm{ml}$, supplemented with SB431542 $10 \mu \mathrm{M}+$ noggin $500 \mathrm{ng} / \mathrm{ml}$ (or dorsomorphin $5 \mu \mathrm{M}$ instead of noggin). The use of this medium avoids excessive cell proliferation during neural induction, and can be used also with Matrigel reduced factors. Media containing KSR have a higher protein content and chemical buffering capacity. In a medium devoid of KSR the concentration of some chemical factors (such as dual SMAD inhibitors) may be reduced, because they might result in toxicity in more sensitive cell lines [14].

\section{Note 4.}

For replating, as alternative from step 51 to 56 follow:

51. Let the dish dry for $15 \mathrm{~min}$ before plating the individual drops (alternatively use poly-D-

lysine/laminin- or Matrigel reduced factors-coated dishes) leaving them under the hood with opened lid.

52. Dilute the Accutase with 4 volumes of PBS $1 \mathrm{X}$ prewarmed at $37^{\circ} \mathrm{C}$.

53. Collect the cells and spin $3 \mathrm{~min}$ at $200 \mathrm{~g}$ at $\mathrm{RT}$ and resuspend the pellet in $0.5 \mathrm{ml}$ of $\mathrm{NBB}_{30}$ medium added with Y-27632 $10 \mu \mathrm{M}$.

54. Count resuspended viable cells by trypan blue staining. It is advisable to make an intermediate dilution before counting because of the high cell density.

55. Dilute the cell suspension to a final concentration of $5 \times 10^{6}$ cells $/ \mathrm{ml}$ in $\mathrm{NBB}_{30}$ medium supplemented with Y-27632 $10 \mu \mathrm{M}$.

56. Spot plate with $20 \mu \mathrm{l}$ drops (i.e.: 4 drops per well of a 12-well plate) of the cell suspension $\left(10^{5}\right.$ cells/drop) and leave cells at $37^{\circ} \mathrm{C}$ in a $5 \% \mathrm{CO}_{2}$ incubator for $20 \mathrm{~min}$ before slowly adding $0.3 \mathrm{ml}$ per well of a 12-well plate of $\mathrm{NBB}_{30}$ medium supplemented with Y-27632 $10 \mu \mathrm{M}$. Move dishes carefully to a $37^{\circ} \mathrm{C}$ and $5 \% \mathrm{CO}_{2}$ incubator and leave overnight.

\section{Note 5.}

Starting from the replating step it is possible to add DAPT $10 \mu \mathrm{M}$ to NBB medium for maximum two weeks (depending on the maturation state of the cells). This treatment accelerates neuronal differentiation [5]. 


\section{Note 6.}

All the critical and diagnostic antibodies employed in the work for the characterization of generating telencephalic progenitors and MSNs were validated on 11 week-old human fetal brain sections [9]. This standardized procedure avoids using unspecific antibodies and allows to have a validated tool for characterization of the differentiation process.

\section{Note 7.}

Some antibodies require specific antigen retrieval procedures, such as FOXG1: unmasking with 1mM EDTA for $10 \mathrm{~min}$ at $65^{\circ} \mathrm{C}$ and wash with PBSX. 


\section{Acknowledgements}

Several other authors have participated in the original paper (Delli Carri et al., 2013). The authors list in this paper accounts for those that have designed and validated the protocol. The research described in our original paper (Delli Carri et al., 2013) and leading to the protocol herein detailed has received funding from NeuroStemcell, European Union Seventh Framework Programme grant agreement $n^{\circ} 222943$, partially from the Ministero dell'Istruzione dell'Università e della Ricerca [MIUR, 2008JKSHKN] and from Cure Huntington's Disease Initiative (CHDI) ID: A-4529 to E.C. and by Fondo per gli Investimenti della Ricerca di Base [FIRB, RBFR10A01S] to M.O.; A.F. was supported by a Marie Curie fellowship. We acknowledge the important contribution of Tavola Valdese (2007-2010) and the support of Unicredit Banca S.p.A. (Italy). We also thank the families of HD patients for their continuous support. 


\section{References}

1. Chambers SM, Fasano CA, Papapetrou EP, Tomishima M, Sadelain M, Studer L. Highly efficient neural conversion of human ES and iPS cells by dual inhibition of SMAD signaling. Nat Biotechnol 2009;27:275-80.

2. Gaspard N, Vanderhaeghen P. From stem cells to neural networks: recent advances and perspectives for neurodevelopmental disorders. Dev Med Child Neurol 2010;53:13-7.

3. Shi Y, Kirwan P, Smith J, Robinson HP, Livesey FJ. Human cerebral cortex development from pluripotent stem cells to functional excitatory synapses. Nat Neurosci 2012;15:477-86, S1.

4. Bissonnette CJ, Lyass L, Bhattacharyya BJ, Belmadani A, Miller RJ, Kessler JA. The controlled generation of functional basal forebrain cholinergic neurons from human embryonic stem cells. Stem Cells 2011;29:802-11.

5. Kriks S, Shim JW, Piao J, et al. Dopamine neurons derived from human ES cells efficiently engraft in animal models of Parkinson's disease. Nature 2011;480:547-51.

6. Kirkeby A, Grealish S, Wolf DA, et al. Generation of regionally specified neural progenitors and functional neurons from human embryonic stem cells under defined conditions. Cell Rep 2012;1:703-14.

7. Aubry L, Bugi A, Lefort N, Rousseau F, Peschanski M, Perrier AL. Striatal progenitors derived from human ES cells mature into DARPP32 neurons in vitro and in quinolinic acidlesioned rats. Proc Natl Acad Sci U S A 2008;105:16707-12.

8. Ma L, Hu B, Liu Y, et al. Human Embryonic Stem Cell-Derived GABA Neurons Correct Locomotion Deficits in Quinolinic Acid-Lesioned Mice. Cell Stem Cell 2012.

9. Delli Carri A, Onorati M, Lelos MJ, et al. Developmentally coordinated extrinsic signals drive human pluripotent stem cell differentiation toward authentic DARPP-32+ medium-sized spiny neurons. Development 2013;140:301-12.

10. Lupo G, Harris WA, Lewis KE. Mechanisms of ventral patterning in the vertebrate nervous system. Nat Rev Neurosci 2006;7:103-14.

11. Sousa VH, Fishell G. Sonic hedgehog functions through dynamic changes in temporal competence in the developing forebrain. Curr Opin Genet Dev 2010;20:391-9.

12. Schuurmans C, Guillemot F. Molecular mechanisms underlying cell fate specification in the developing telencephalon. Curr Opin Neurobiol 2002;12:26-34.

13. Camnasio S, Carri AD, Lombardo A, et al. The first reported generation of several induced pluripotent stem cell lines from homozygous and heterozygous Huntington's disease patients demonstrates mutation related enhanced lysosomal activity. Neurobiol Dis 2012;46:41-51. 14. Kirkeby A, Nelander J, Parmar M. Generating regionalized neuronal cells from pluripotency, a step-by-step protocol. Front Cell Neurosci 2012;6:64. 


\section{Figure legends}

Fig. 1 Protocol outline. Human pluripotent stem (hPS) cells in self-renewing condition are exposed to the striatal differentiation protocol. The main cell types emerging during the 80-day process are represented. Cell density during plating steps (day -2 and replating at day 15 ) are indicated, as well as the cell substrates. The media at each stage are mentioned: for neural induction KSR at different ratios with N2 medium and NBB medium for terminal differentiation (see "Solutions"). The addition of growth factors (GF), morphogens (MO) and neurotrophins (NT) is illustrated. During the different stages, the emerging cell populations are defined by the expression of specific combination of diagnostic markers. Fully mature neurons exhibit specific electrophysiological hallmarks (italics). A genome-wide gene expression analysis performed at different stages of differentiation reveals the enrichment for specific gene ontology (GO) classes. * see Note $4, * *$ see Note $2, * * *$ see Note 3.

Fig. 2 Neural conversion and ventral telencephalic commitment of hPS cells. (a) Live image of confluent hPS cells at day 0 of differentiation. (b-e) At day 15 of differentiation the cells express nestin (b) and are double positive for PAX6 (c). SOX1 (d) and the telencephalic marker FOXG1 (e) expression are shown. (f) At day 26 the generated progenitors strongly express GSX2.

Fig. 3 Terminal differentiation of striatal progenitors towards MSNs. After 80 days of differentiation the generated neurons express (a) BIII-tubulin, (b) GAD65/67, (c) calbindin, (d) MAP2 and FOXP1. (e) The cells are double positive for CTIP2 and FOXP2. (f) Cells also express DARPP-32. (g) Confocal analysis confirming MSN identity by co-expression of CTIP2 and DARPP-32 (original magnification 40x). D-32: DARPP-32.

Fig. 4 Electrophysiological properties of fully differentiated neurons. (a) Sample trace obtained in currentclamp configuration shows repetitive firing in an 80 day differentiated neuron when excited with a suprathreshold depolarizing step of current. (b) Family of total inward and outward currents elicited at test 
potentials ranging from -70 to $+40 \mathrm{mV}$ from a holding voltage of $-90 \mathrm{mV}$. (c) Local application of GABA $(20 \mu \mathrm{M})$ at $-80 \mathrm{mV}$ elicits an inward current. (d) Family of transient $I_{A}$ potassium currents in isolation obtained by subtracting the current traces elicited at test potentials ranging from -70 to $+40 \mathrm{mV}$, following a conditioning pulse at $-110 \mathrm{mV}$, from those elicited at the same test potentials preceded by a prepulse at -40 $\mathrm{mV}$. 


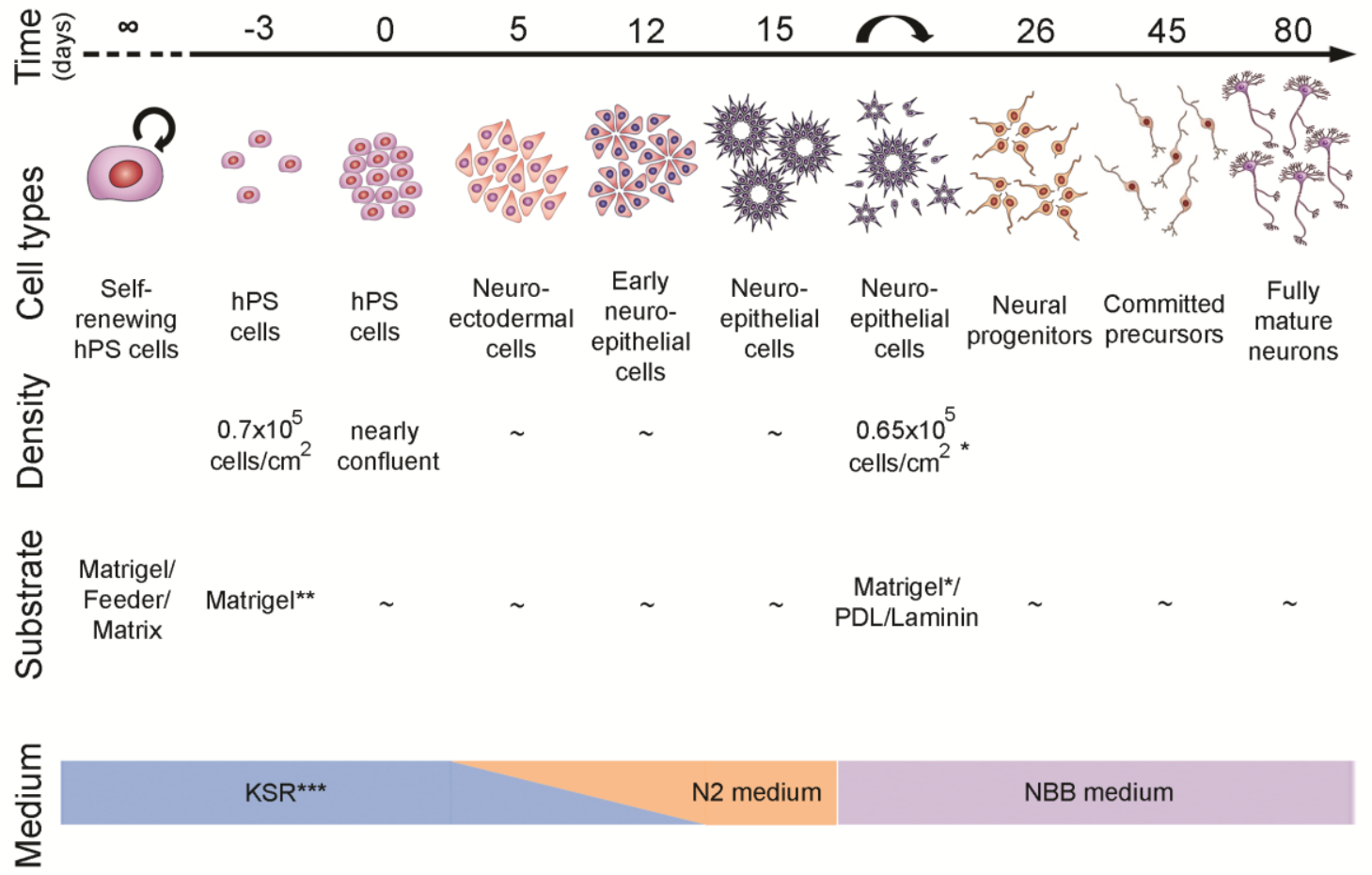

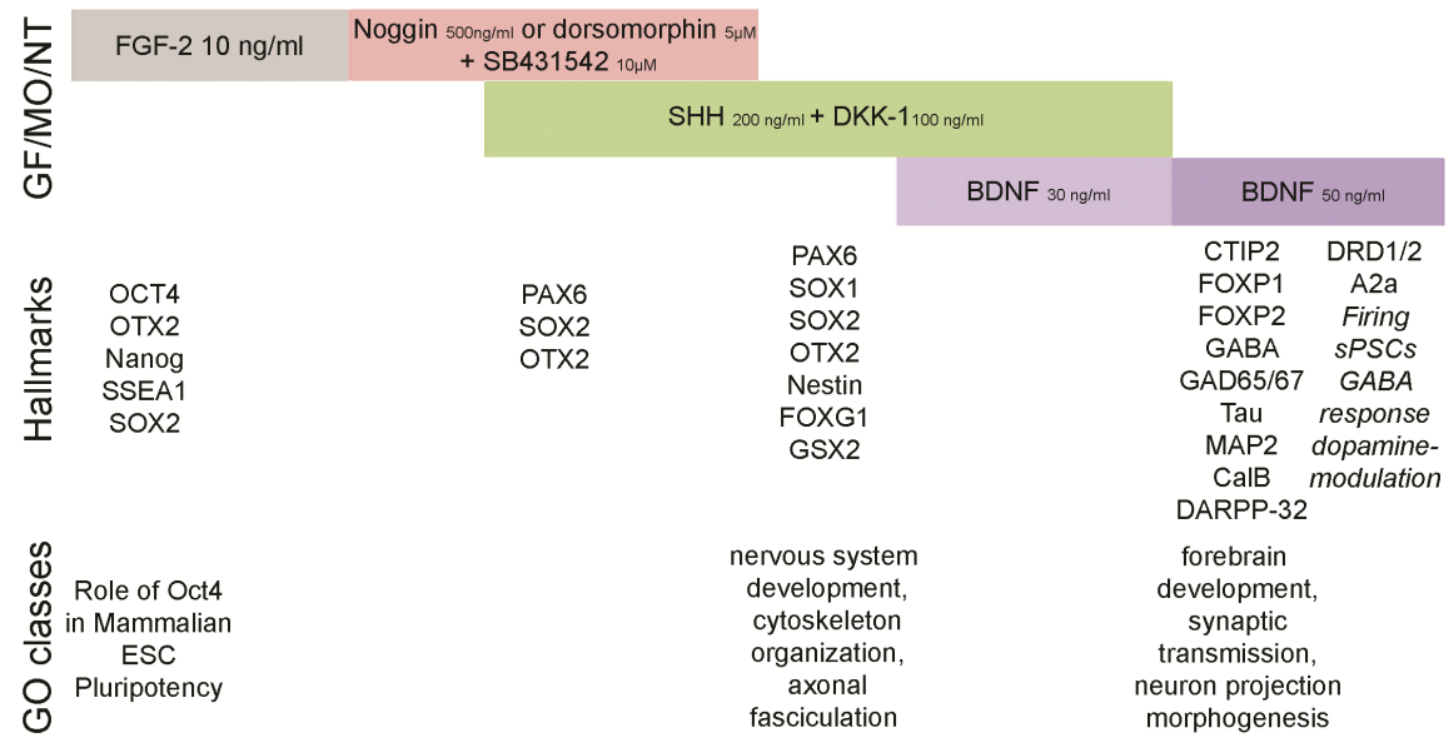



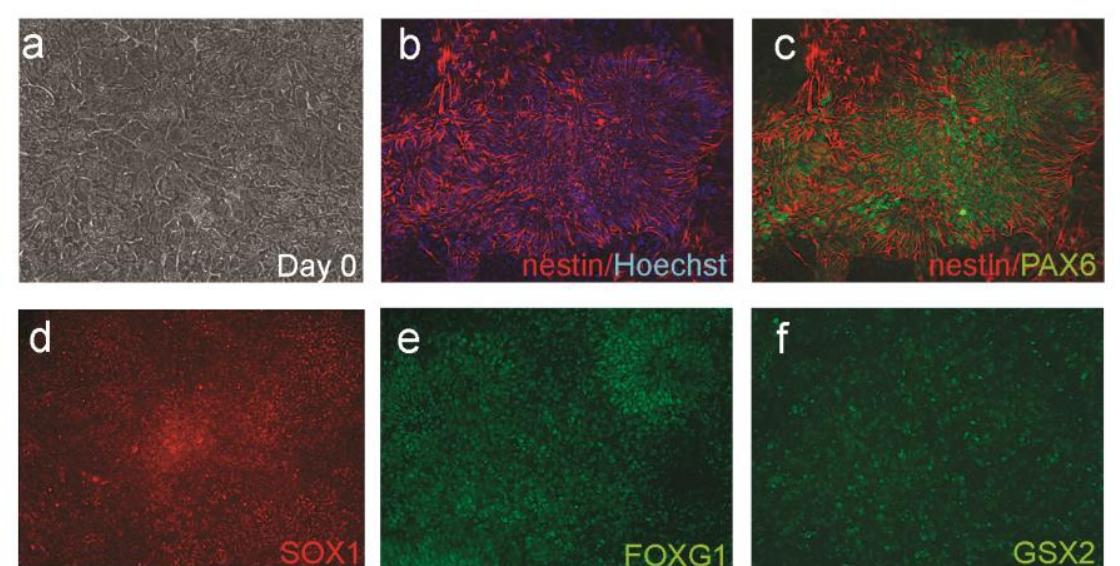

f

GSX2 

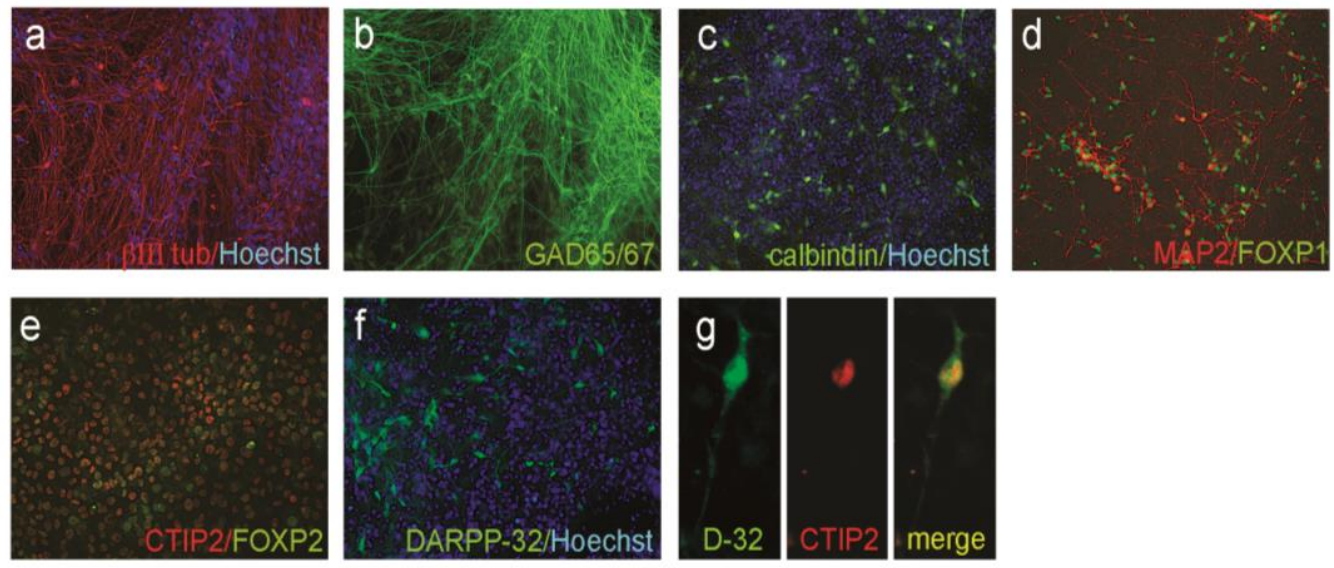


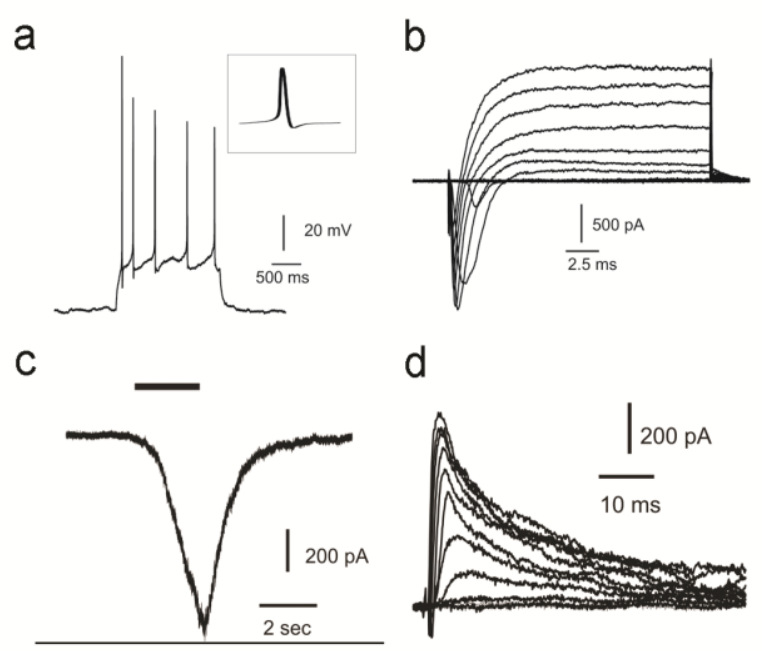

